\title{
Characterization of the human liver vasopressin receptor
}

\section{Profound differences between human and rat vasopressin-receptor-mediated responses suggest only a minor role for vasopressin in regulating human hepatic function}

\author{
John HOWL, ${ }^{*}$ Tariq ISMAIL, $\dagger$ Alastair J. STRAIN, ${ }^{*} \dagger$ Christopher J. KIRK, ${ }^{*}$ David ANDERSON, ${ }^{*} \dagger$ \\ and Mark WHEATLEY* $\ddagger$ \\ *School of Biochemistry, University of Birmingham, and †Liver Unit, Queen Elizabeth Hospital, Birmingham B15 2TT, U.K.
}

\begin{abstract}
The [Arg $\left.{ }^{8}\right]$ vasopressin (AVP) receptor expressed by human hepatocytes was characterized, and compared with the rat hepatic $\mathrm{V}_{1 \mathrm{~s}}$ vasopressin receptor subtype. In addition to determining the pharmacological profile of the human receptor, the cellular responses to AVP were measured in human and rat hepatocytes by assaying glycogen phosphorylase $a$ activity and DNA synthesis. Marked differences were observed between human and rat hepatocytes regarding vasopressin receptors and the intracellular consequences of stimulation by AVP. Data presented in this paper demonstrate the following. (i) Vasopressin $V_{1 \mathrm{~s}}$ receptors are present in low abundance on human hepatocytes. (ii) Species differences exist between human and rat $\mathrm{V}_{1 \mathrm{a}}$ receptors with respect to the affinity of some selective antagonists. (iii) AVP-stimulated glycogen phosphorylase $a$ activation in human hepatocytes was approx. $5 \%$ of that observed in rat cells. (iv) In contrast with rat hepatocytes, DNA synthesis in human cells in culture was not stimulated by AVP. It is concluded that vasopressin plays only a minor role in the regulation of human hepatic function. Furthermore, conclusions drawn from observations made with AVP and its analogues on rat hepatic function cannot be directly extrapolated to the human situation.
\end{abstract}

\section{INTRODUCTION}

The neurohypophysial hormone $\left[\mathrm{Arg}^{8}\right]$ vasopressin (AVP) has a variety of physiological effects, including well-characterized pressor and antidiuretic activities (reviewed by Jard, 1983). In common with many other hormones and neurotransmitters, AVP exerts its actions through more than one type of receptor. Michell et al. (1979) classified these vasopressin receptor subtypes according to the effector system to which they are coupled: $V_{1}$ receptors stimulate phosphoinositidase $\mathrm{C}$ to generate the second messengers Ins $(1,4,5) P_{3}$ and diacylglycerol (Berridge \& Irvine, 1984), whereas $V_{2}$ receptors stimulate adenylate cyclase. $V_{1}$ receptors are expressed in vascular smooth muscle, where they mediate the vasopressor response, and $\mathrm{V}_{2}$ receptors are located in the renal tubule, where they regulate antidiuresis (Michell et al., 1979). More recently, inconsistencies in the pharmacological profile of $\mathrm{V}_{1}$ receptors in vascular smooth muscle and the anterior pituitary gland (Knepel et al., 1983; Antoni, 1984; Baertschi \& Friedli, 1985; Raymond et al., 1985) have resulted in a further sub-classification of these receptors into $V_{1 \mathrm{a}}$ (smooth muscle) and $V_{1 \mathrm{~b}}$ (anterior pituitary) (Jard et al., 1986).

The vasopressin receptor expressed by mammalian hepatocytes is the $\mathrm{V}_{1}$ subtype, as indicated by its pharmacological characteristics (Kirk et al., 1979; Keppens \& DeWulf, 1979; Cantau et al., 1980 ) and by the effector system to which it couples (Kirk \& Hems, 1974; Keppens et al., 1977; Kirk et al., 1981). AVP occupancy of these receptors rapidly initiates glycogenolysis (Hems \& Witton, 1973, 1980) by stimulating the conversion of glycogen phosphorylase $b$ to glycogen phosphorylase $a$ (Keppens \& DeWulf, 1975; Cantau et al., 1980). In addition, prolonged exposure to AVP in vivo enhanced the rate of liver regeneration in the genetically AVP-deficient Brattleboro rat following partial hepatectomy (Russell \& Bucher, 1983a) and potentiated DNA synthesis in primary cultures of normal rat hepatocytes (Russell \& Bucher, 1983b). These studies of the characteristics of the $V_{1 a}$ receptor expressed in liver, and of the physiological role of AVP in hepatic function, have predominantly utilized rodenț as the tissue source. Observations made using rodent liver are then often extrapolated to other mammals, including man. Access to normal healthy human liver has enabled us to study the $V_{1 a}$ receptor of human liver directly.

In this paper, the $\mathrm{V}_{1 \mathrm{~g}}$ receptor expressed by human hepatocytes is compared with the rat liver vasopressin receptor by investigating three different parameters of hepatic vasopressin receptor function. The receptor protein is studied directly in liver cell membranes using radioligand-binding techniques. The shortterm and long-term physiological consequences of agonist activation of this receptor in hepatocytes (i.e. glycogenolysis and DNA synthesis) are appraised by assaying the activity of glycogen phosphorylase $a$ and the incorporation of $\left[{ }^{3} \mathrm{H}\right]$ thymidine into DNA respectively. Our data indicate that profound differences exist between the human and rat liver $\mathrm{V}_{1 \mathrm{a}}$ receptors with respect to all three parameters studied, thereby making extrapolation from rat liver to human liver invalid with regard to AVP function.

\section{MATERIALS AND METHODS}

[Phe-3,4,5- ${ }^{3} \mathrm{H}$ AVP $(67.7 \mathrm{Ci} / \mathrm{mmol})$, the labelled $\mathrm{V}_{1 \mathrm{a}}$-selective vasopressin antagonist $\left[\right.$ Phe-3,4,5- $\left.{ }^{3} \mathrm{H}\right]\left[\mathrm{d}\left(\mathrm{CH}_{2}\right)_{5}-\mathrm{Tyr}(\mathrm{Me})^{2}\right] \mathrm{AVP}$ (Kruszynski et al., 1980$)(56.2 \mathrm{Ci} / \mathrm{mmol})$ and $\alpha-\mathrm{D}-\left[\mathrm{U}-{ }^{14} \mathrm{C}\right] \mathrm{glucose}$ 1-phosphate $(313 \mathrm{mCi} / \mathrm{mmol})$ were from NEN. $\left[\mathrm{Me}^{-}{ }^{3} \mathrm{H}\right] \mathrm{Thymi}-$ dine $(5 \mathrm{Ci} / \mathrm{mmol})$ and $m y o-\left[2-{ }^{3} \mathrm{H}\right]$ inositol $(108.4 \mathrm{Ci} / \mathrm{mmol})$ were from Amersham. The unlabelled peptides AVP, $\left[\mathrm{d}\left(\mathrm{CH}_{2}\right)_{5}\right.$ $\left.\operatorname{Tyr}(\mathrm{Me})^{2}\right] A V P$, des-Gly ${ }^{9}-\left[\mathrm{d}\left(\mathrm{CH}_{2}\right)_{5}-\mathrm{D}-\mathrm{Tyr}(\mathrm{Et})^{2}\right]$ VAVP (a vaso-

Abbreviations used: $\mathrm{EC}_{50}$, concn. of ligand producing a $50 \%$ activation; $\mathrm{IC}_{50}$, concn. of ligand producing $50 \%$ inhibition; EGF, epidermal growth factor; $K_{\mathrm{d}}$, dissociation constant $\left\{\mathrm{p} K_{\mathrm{d}}\right.$ is $\left.-\log \left[K_{\mathrm{d}}(\mathrm{M})\right]\right\}$; PBS, phosphate-buffered salt solution; AVP, [Arg $]$ vasopressin (other vasopressin analogue abbreviations are given in the legend to Table 1); OT, oxytocin.

$\ddagger$ To whom correspondence should be addressed, at: School of Biochemistry, University of Birmingham, Edgbaston, Birmingham B15 2TT, U.K. 
pressin antagonist with selectivity for $\mathrm{V}_{1 \mathrm{a}} / \mathrm{V}_{1 \mathrm{~b}}$; Jard et al., 1986; see the legend to Table 1 for definition of abbreviations) and the selective oxytocin (OT) agonist $\left[\mathrm{Thr}^{4}, \mathrm{Gly}^{7}\right] \mathrm{OT}$ (Lowbridge et al., 1977) were obtained from Bachem. The $V_{2}$-selective vasopressin antagonist $\left[\mathrm{d}\left(\mathrm{CH}_{2}\right)_{5}-\mathrm{D}-\mathrm{Ile}^{2}\right.$,Ile $\left.{ }^{4}\right] \mathrm{AVP}$ (Manning et al., 1984) was from Peninsula Laboratories. OT was from Ferring. Phenylephrine, bacitracin, epidermal growth factor (EGF), dispase, deoxyribonuclease and hyaluronidase were from Sigma. Glucagon was from Novo. Collagenase (type H) was from Boehringer.

Adult Wistar rats (200-250 g) of either sex were obtained from the University of Birmingham animal house, having been fed on a normal laboratory diet with free access to water. After killing the animal, the whole liver was rapidly removed and membranes were prepared. Normal human liver was obtained from braindead multiple organ donors as part of an ongoing liver transplant programme in the Queen Elizabeth Hospital, Birmingham. Perfusion of human liver in situ with cold Marshall's solution (Ross et al., 1976) or University of Wisconsin solution (Belzer \& Southard, 1988) was performed before surgical removal. Samples became available following graft reduction for paediatric recipients. Samples of human liver were either rapidly frozen in liquid $\mathrm{N}_{2}$ and stored at $-75^{\circ} \mathrm{C}$ or used immediately for the production of hepatocytes or liver membranes.

\section{Preparation of liver membranes}

Frozen human liver samples were allowed to thaw on ice before proceeding further. A partially purified liver membrane preparation from rat or human was obtained according to the method of Dickey et al. (1987), with minor modifications. Briefly, samples were homogenized by 8 strokes of a Teflon/glass homogenizer in 4 vol. of ice-cold buffer A (20 mM-Hepes, $10 \mathrm{~mm}$ magnesium acetate, $1 \mathrm{~mm}$-EGTA, $0.25 \mathrm{M}$-sucrose and $1 \mathrm{mg}$ of bacitracin $/ \mathrm{ml}, \mathrm{pH}$ 7.4) supplemented with the proteinase inhibitors leupeptin and antipain (each $5 \mu \mathrm{g} / \mathrm{ml}$ ) for the homogenization step only. The homogenate was centrifuged at $8000 \mathrm{~g}$ for $10 \mathrm{~min}$ at $4{ }^{\circ} \mathrm{C}$, the pellet discarded and the supernatant centrifuged further $\left(70000 \mathrm{~g}\right.$ for $60 \mathrm{~min}$ at $\left.4^{\circ} \mathrm{C}\right)$. At this stage, the upper microsomal layer was separated from the more dense glycogen pellet and resuspended by homogenization in fresh buffer A. A crude membrane fraction was sedimented at $40000 \mathrm{~g}$ for $60 \mathrm{~min}$ and resuspended in $2 \mathrm{ml}$ of buffer $\mathrm{A} / \mathrm{g}$ wet wt. of original tissue. Membranes were stored in $1 \mathrm{ml}$ portions at $-20{ }^{\circ} \mathrm{C}$ for up to 3 months with no detectable loss of binding.

The protein content of membranes was determined with the Pierce BCA assay using BSA (Sigma) as standard, and typically ranged from 3 to $8 \mathrm{mg}$ of total protein $/ \mathrm{ml}$.

\section{Binding assays}

Membranes were thawed, diluted in buffer B (20 mM-Hepes, $10 \mathrm{~mm}$-magnesium acetate, $1 \mathrm{~mm}-\mathrm{EGTA}$ and $1 \mathrm{mg}$ of $\mathrm{BSA} / \mathrm{ml}$, pH 7.4), and then added to $\left[{ }^{3} \mathrm{H}\right]$ ligand and unlabelled competing ligands, present at the concentrations indicated, to give a final volume of $500 \mu \mathrm{l}$ containing $100 \mu \mathrm{g}$ of membrane protein. Binding incubations were for $90 \mathrm{~min}$ at $30^{\circ} \mathrm{C}$, which allowed equilibrium to be established, and were terminated by centrifugation for $5 \mathrm{~min}$ at $10000 \mathrm{~g}$. After superficial washing, the membrane pellet was solubilized using Soluene 350 (Packard) mixed with scintillation cocktail and counted for radioactivity by liquid scintillation spectroscopy. Non-specific binding was defined by inclusion of excess AVP ( $4 \mu \mathrm{M})$ in the binding assay and was subtracted from total binding to obtain receptor-specific binding. $\mathrm{IC}_{50}$ values (concns. of ligand producing $50 \%$ inhibition) derived from competition binding experiments with $\left[{ }^{3} \mathrm{H}\right] \mathrm{AVP}$ were corrected for occupancy using the $K_{\mathrm{d}}$ of [ $\left.{ }^{3} \mathrm{H}\right] \mathrm{AVP}(0.59 \mathrm{nM})$ according to the method of Cheng \& Prusoff (1973).
H.p.l.c. was used to investigate the stability of vasopressin analogues during incubation with liver membranes. After incubation for various times, membranes were pelleted and the supernatant subjected to h.p.l.c. analysis on a Spherisorb $C_{18}$ reverse-phase column (Phase Sep, Deeside, U.K. Peptides were eluted using a linear gradient of $5-65 \%$ acetonitrile $/ 0.1 \%$ trifluoroacetic acid over $30 \mathrm{~min}$ and absorbance was monitored at $220 \mathrm{~nm}$.

\section{Adenylate cyclase assay}

Adenylate cyclase activity in human liver samples was measured using a protocol identical to that described by Keen et al. (1989), based on the method of Sharma et al. (1975). Assays were performed in triplicate using $100 \mu \mathrm{g}$ of total membrane protein. Cyclic $\left[{ }^{32} \mathrm{P}\right] \mathrm{AMP}$ generated during the assay was separated from its precursor $\left[\alpha-{ }^{32}\right.$ P]ATP using a two-step chromatographic procedure (Salomon et al., 1974), and values of recovered cyclic [ $\left.{ }^{32} \mathrm{P}\right] A M P$ were adjusted for losses on the columns by comparison with losses of cyclic $\left[{ }^{3} \mathrm{H}\right] \mathrm{AMP}$ standard.

\section{Preparation of hepatocytes}

Rat hepatocytes were prepared from the whole livers of male Wistar rats using the two-step collagenase method of McGowan et al. (1981), except that the initial perfusion medium was a $\mathrm{Ca}^{2+}$, $\mathrm{Mg}^{2+}$-free Krebs-Ringer bicarbonate buffer with Hepes (120 mM-NaCl, $4.7 \mathrm{~mm}-\mathrm{KCl}, 11.5 \mathrm{~mm}$-glucose, $25 \mathrm{~mm}-\mathrm{NaHCO}_{3}$ and $10 \mathrm{~mm}$-Hepes, pH 7.4). The yield of rat hepatocytes was $(2-3) \times 10^{7}$ cells $/ \mathrm{g}$ wet wt.

Human hepatocytes were prepared from an unused portion of donor liver. A wedge (100-200 g) of human liver with one cut surface was cannulated with two $16 \mathrm{G}$ venflons. Perfusion details were similar to those described for the rat (see above), except that the $\mathrm{Ca}^{2+}$-free perfusion medium was supplemented with EGTA $(0.5 \mathrm{~mm})$ and the enzyme mixture contained collagenase $(0.5 \mathrm{mg} / \mathrm{ml})$, dispase $(1 \mathrm{mg} / \mathrm{ml})$, deoxyribonuclease $(0.05 \mathrm{mg} / \mathrm{ml})$ and hyaluronidase $(0.5 \mathrm{mg} / \mathrm{ml})$. After about $30 \mathrm{~min}$ of enzyme recirculation $(50 \mathrm{ml} / \mathrm{min})$, and once softening of the liver was observed, perfusion was terminated and the liver was minced and agitated to disaggregate the cells. Cells were isolated and washed three times by centrifugation $(50 \mathrm{~g}, 2 \mathrm{~min})$ and resuspension in perfusion buffer supplemented with $10 \%(\mathrm{v} / \mathrm{v})$ fetal calf serum. The yield of human hepatocytes from one liver portion prepared in this manner was in the range $(2-5) \times 10^{6}$ cells/g wet wt.

The viability of all hepatocyte preparations was assessed by the Trypan Blue exclusion method and was $90-95 \%$ for rat hepatocytes and 75-95\% for human hepatocytes. The metabolic integrity of the hepatocyte preparations was established by assaying the ATP content of the cells using a bioluminescent assay kit (Sigma) according to the manufacturers' instructions. The ATP content of rat and human hepatocytes was $5.5 \pm 0.4$ $(n=5)$ and $6.2 \pm 1.0(n=3) \mathrm{pg} /$ cell respectively, $24 \mathrm{~h}$ after the initiation of culture. This is comparable with the $7.5 \mathrm{pg} /$ cell previously reported for viable rat hepatocytes (Baur et al., 1975). These values did not vary significantly from the time of hepatocyte production to the end of the experiment. The measured ATP content corresponds to a tissue concentration of $2.4-2.7 \mu \mathrm{mol} / \mathrm{g}$ of tissue, which is similar to that reported in vivo and for perfused liver (Hems et al., 1966). The metabolic integrity of the hepatocytes was corroborated by the observation that the hepatocytes' DNA repair mechanisms were intact (Dr. J. K. Chipman, personal communication) and that the cells were responsive to hepatocyte growth factor (Strain et al., 1991).

\section{Stimulation and assay of glycogen phosphorylase $a$ activity}

The protocol used for hormonal stimulation of glycogen phosphorylase (EC 2.4.1.1) was based upon the method of Kirk 
et at. (1979). Briefly, freshly prepared hepatocytes were transferred to perfusion medium supplemented with $1.8 \mathrm{mM}-\mathrm{CaCl}_{2}$, $1.2 \mathrm{~mm}-\mathrm{MgCl}_{2}$ and BSA $(2 \mathrm{mg} / \mathrm{ml})$, and $450 \mu \mathrm{l}$ portions (approx. $5 \times 10^{6} \mathrm{cells} / \mathrm{ml}$ ) were preincubated for $30 \mathrm{~min}$ at $37^{\circ} \mathrm{C}$. Hormones were then added to the cell suspension and the medium was briefly flushed with $\mathrm{O}_{2} / \mathrm{CO}_{2}(19: 1)$ before incubation at $37^{\circ} \mathrm{C}$ in a shaking water bath $(80-90 \mathrm{cycles} / \mathrm{min})$. Incubations were terminated after $2 \mathrm{~min}$ by rapidly pipetting $400 \mu \mathrm{l}$ of cell suspension into sample tubes precooled in liquid $\mathrm{N}_{2}$. Samples were stored at $-75^{\circ} \mathrm{C}$ before assay. After adding to the frozen sample $400 \mu \mathrm{l}$ of an ice-cold medium containing $100 \mathrm{~mm}$ glycylglycine and $200 \mathrm{~mm}-\mathrm{NaF}, \mathrm{pH} \mathrm{7.4}$, the hepatocytes were homogenized at $0^{\circ} \mathrm{C}$ using 20 strokes of a Teflon/glass homogenizer. Entry of the fluorescent dye Procion Yellow MX$4 R$ into cells validated the effectiveness of this homogenization protocol.

Glycogen phosphorylase $a$ activity was assayed by measuring the incorporation of radioactive glucose from $\left[{ }^{14} \mathrm{C}\right]$ glucose 1phosphate into glycogen at $30^{\circ} \mathrm{C}$ (Hems et al., 1976). A $50 \mu \mathrm{l}$ portion of homogenate was added to $50 \mu$ l of an assay medium containing $30 \mathrm{~mm}-\left[{ }^{14} \mathrm{C}\right]$ glucose 1-phosphate, $20 \mathrm{mg}$ of glycogen $/ \mathrm{ml}$ (pretreated with Amberlite MB-1), $200 \mathrm{mM}-\mathrm{KF}$, $20 \mathrm{~mm}$-EDTA, $1 \mathrm{~mm}$-caffeine and $66 \mathrm{~mm}$-Mes, $\mathrm{pH} 6.3$, at $30^{\circ} \mathrm{C}$. After $20 \mathrm{~min}$, the reaction was stopped by the addition of $400 \mu \mathrm{l}$ of ice-cold $6 \%(\mathrm{w} / \mathrm{v})$ trichloroacetic acid containing glycogen $(1 \mathrm{mg} / \mathrm{ml})$ and $\mathrm{LiBr}(2 \mathrm{mg} / \mathrm{ml})$. Glycogen was precipitated by ethanol $(800 \mu \mathrm{l})$, pelleted $(10000 \mathrm{~g}, 30 \mathrm{~s})$ and washed twice by resuspension in water and ethanol precipitation. The washed glycogen pellet was resuspended in water and incorporated radioactivity was determined by liquid scintillation spectroscopy.

\section{Maintenance of hepatocyte cultures}

Hepatocytes were plated on to rat-tail-collagen-coated Petri dishes (Strain et al., 1982) at a density $3 \times 10^{5}$ cells/dish (Falcon; $35 \mathrm{~mm}$ ) in a volume of $2 \mathrm{ml}$ (Dulbecco's minimal essential medium $\pm 10 \%$ fetal calf serum). Following attachment (30 min for rat, $2 \mathrm{~h}$ for human), cells were washed twice in phosphatebuffered saline (PBS; ICN-Flow Laboratories) and maintained in $1.5 \mathrm{ml}$ of culture medium (modified arginine-free Williams' $\mathrm{E}$ medium; Imperial Laboratories) supplemented with $2 \mathrm{mM}-\mathrm{L}-$ glutamine, $0.4 \mathrm{~mm}$-ornithine, $5.5 \mu \mathrm{M}$-cortisol, 100 units of penicillin $/ \mathrm{ml}, 100 \mu \mathrm{g}$ of streptomycin $/ \mathrm{ml}$ and $0.1 \mu \mathrm{M}$-insulin at $37^{\circ} \mathrm{C}$ in a $\mathrm{CO}_{2}$ /air $(1: 19)$ humidified incubator. Medium was renewed every $24 \mathrm{~h}$.

\section{Measurement of inositol phosphate production}

Human hepatocytes were prepared as described previously and distributed on to $35 \mathrm{~mm}$-diam. culture dishes at a density of $3 \times 10^{5}$ cells $/$ dish. After $2 \mathrm{~h}$, the dishes were washed twice with culture medium to remove dead and non-adherent cells. Hepatocytes were then labelled in full culture medium with myo-[2${ }^{3} \mathrm{H}$ ]inositol $(10 \mu \mathrm{Ci} / \mathrm{ml})$ for $18 \mathrm{~h}$ before washing them twice to remove exogenous label and replacing the medium with one containing $10 \mathrm{~mm}-\mathrm{LiCl}$. After $15 \mathrm{~min}$, hepatocytes were challenged with agonists and incubations were quenched, after a further period of $15 \mathrm{~min}$, with $\mathrm{HClO}_{4}$ (final concn. $5 \%$, w/v). Inositol phosphates were extracted and separated as described by Kirk et al. (1986), except that an Ins $P_{1}-\operatorname{Ins} P_{4}$ fraction was eluted from $0.8 \mathrm{ml}$ columns of Bio-Rad AG1-X8 anion-exchange resin with $10 \mathrm{ml}$ of $1.05 \mathrm{M}$-ammonium formate/0.1 M-formic acid.

\section{Assay of $\left[{ }^{3} \mathbf{H}\right]$ thymidine incorporation into DNA}

DNA synthesis in primary hepatocyte cultures was determined by measuring the incorporation of $\left[{ }^{3} \mathrm{H}\right]$ thymidine into DNA (McGowan et al., 1981). [ $\left.{ }^{3} \mathrm{H}\right]$ Thymidine $(1 \mu \mathrm{Ci} / \mathrm{ml})$ was added to hepatocyte cultures for the final $24 \mathrm{~h}$ of a $72 \mathrm{~h}$ period. Compounds (AVP, EGF) tested for their ability to enhance DNA synthesis were present in the medium for the entire $72 \mathrm{~h}$ incubation period. DNA was extracted and hydrolysed (McGowan et al., 1981), and radioactivity was determined by liquid scintillation spectroscopy.

\section{RESULTS}

\section{Pharmacological characterization of the human hepatic} vasopressin receptor

$\left[{ }^{3} \mathrm{H}\right] A V P$ and the $\mathrm{V}_{1 \mathrm{a}}$-selective ligand $\left[{ }^{3} \mathrm{H}\right]\left[\mathrm{d}\left(\mathrm{CH}_{2}\right)_{5}\right.$ Tyr(Me $)^{2}$ AVP were appraised for their suitability as radiolabelled tracer ligands for studying the human liver vasopressin receptor. Binding studies were performed using 12 human liver membrane preparations derived from 10 different donors of both sexes ranging in age from 4 to 47 years. Analysis by h.p.l.c. revealed that both of these ligands were stable to proteolysis for up to $48 \mathrm{~h}$ when incubated with either human or rat liver membranes under the incubation conditions used. It was found that the binding of $\left[{ }^{3} \mathrm{H}\right]\left[\mathrm{d}\left(\mathrm{CH}_{2}\right)_{5}-\mathrm{Tyr}(\mathrm{Me})^{2}\right] \mathrm{AVP}$, which is our preferred tracer ligand for the rat $\mathrm{V}_{1 \mathrm{a}}$ receptor $\left(K_{\mathrm{d}}=0.28 \mathrm{nM}\right)$, displayed a poor specific/non-specific binding ratio with human liver membranes. Consequently, $\left[{ }^{3} \mathrm{H}\right] \mathrm{AVP}$ was employed routinely in all subsequent experiments. Membranes prepared from different human donors exhibited variable amounts of specific $\left[{ }^{3} \mathrm{H}\right]$ AVP binding. However, the level of specific binding observed did not correlate with either the age or the sex of the donor. Non-specific binding was similar for all samples. To ensure that freezing human liver samples did not have a deleterious effect upon vasopressin receptors, membranes were prepared either from a fresh portion of human liver or from a sample of the same liver that had been frozen by immersion in liquid $\mathrm{N}_{2}$ and stored at $-75^{\circ} \mathrm{C}$. $\left[{ }^{3} \mathrm{H}\right] \mathrm{AVP}$ binding was found to be unaffected by this procedure. This is in agreement with our finding that similar freezing and cold storage of whole rat liver before membrane preparation does not alter the binding parameters of the rat liver $\mathrm{V}_{1 \mathrm{a}}$ receptor (results not shown).

The affinity of $\left[{ }^{3} \mathrm{H}\right] A V P$ for the human vasopressin receptor was determined by saturation binding analysis in three human liver membrane preparations chosen because they exhibited a relatively high $\left[{ }^{3} \mathrm{H}\right] \mathrm{AVP}$ binding capacity. Analysis showed that

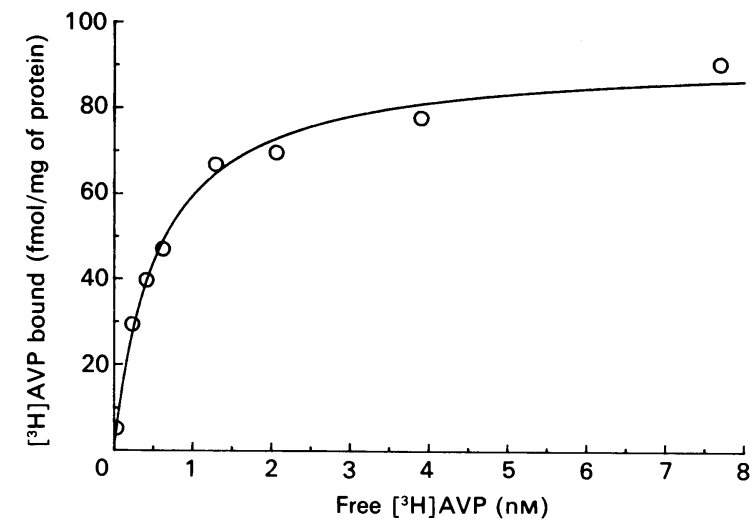

Fig. 1. Saturation binding analysis of the human liver vasopressin receptor

Total, and non-specific, binding of $\left[{ }^{3} \mathrm{H}\right] \mathrm{AVP}$ were determined in triplicate. Specific binding was calculated as the difference between total and non-specific binding and is plotted as a function of the free $\left[{ }^{3} \mathrm{H}\right] A V P$ concentration. Data in this Figure were obtained using a membrane preparation of a liver sample derived from a 36-year-old male donor, and the curve is representative of similar results using two other samples. Specific binding of $\left[{ }^{3} \mathrm{H}\right] A$ VP was saturable and of high affinity, with a $K_{d}$ of $0.59 \pm 0.04$ nM (mean \pm S.E.M., $\left.n=3\right)$. 


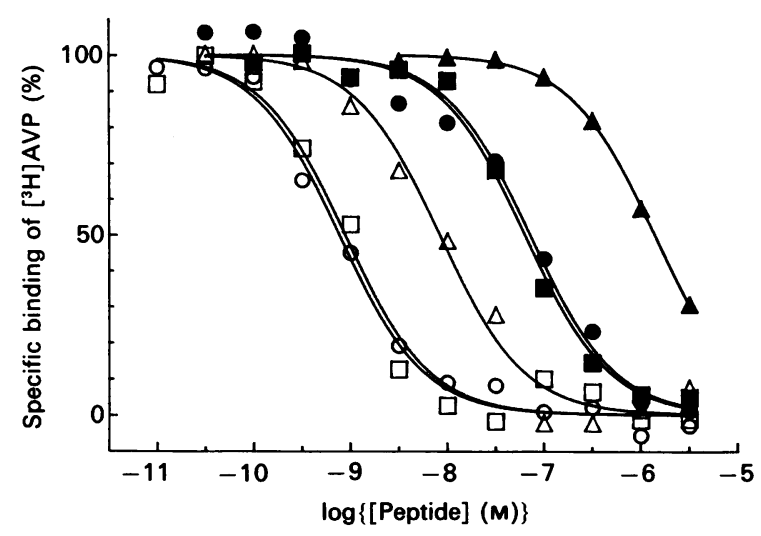

Fig. 2. Determination of dissociation constants of structural vasopressin analogues for the human liver vasopressin receptor

Membrane preparations from three human liver samples obtained from different donors were incubated in the presence of 0.5-1 nM$\left[{ }^{3} \mathrm{H}\right] \mathrm{AVP}$ and various concentrations of unlabelled peptides: $O$, AVP; $\square$, des-Gly'-[d( $\left.\left.\mathrm{CH}_{2}\right)_{5}-\mathrm{D}-\mathrm{Tyr}(\mathrm{Et})^{2}\right]$ VAVP; $\triangle, \quad\left[\mathrm{d}\left(\mathrm{CH}_{2}\right)_{5}-\right.$

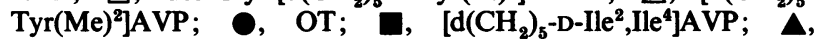
$\left[\mathrm{Thr}^{4}, \mathrm{Gly}^{7}\right] \mathrm{OT}$. Values for the specific binding of $\left[{ }^{3} \mathrm{H}\right] \mathrm{AVP}$ in the presence of unlabelled peptide are expressed as a percentage of specific binding in the absence of competing peptide. All data shown in this Figure were obtained with the same membrane preparation, and curves represent the best fit of a simple Langmuir isotherm to the experimental data. Calculated $K_{\mathrm{d}}$ values for unlabelled peptides were as follows (mean \pm S.E.M., $n=3$ ): des-Gly'-[d $\left(\mathrm{CH}_{2}\right)_{5}-\mathrm{D}-$ Tyr(Et) $\left.)^{2}\right]$ VAVP, $0.54 \pm 0.03 \mathrm{nM} ;\left[\mathrm{d}\left(\mathrm{CH}_{2}\right)_{5}-\mathrm{Tyr}(\mathrm{Me})^{2}\right] A V P, 2.7 \pm$ $0.5 \mathrm{nM}$; OT, $16.3 \pm 4.2 \mathrm{nM}$; [d( $\left.\left.\mathrm{CH}_{2}\right)_{5}-\mathrm{D}-\mathrm{Ile}^{2}, \mathrm{Ile}^{4}\right] \mathrm{AVP}, 30.0 \pm$ $8.0 \mathrm{nM} ;\left[\mathrm{Thr}^{4}, \mathrm{Gly}^{7}\right] \mathrm{OT}, 646 \pm 72 \mathrm{nM}$.

the specific binding of $\left[{ }^{3} \mathrm{H}\right] \mathrm{AVP}$ in each human sample was saturable and was to a single class of site (Fig. 1) with a $K_{d}$ of $0.59 \pm 0.04 \mathrm{nM}$ (mean \pm S.E.M., $n=3$ ). This is comparable with the affinity of the rat liver receptor $\left(K_{d} 0.68 \pm 0.14 \mathrm{nM}\right.$; mean \pm S.E.M., $n=5$ ). Calculation of the number of AVP-binding sites expressed by human liver membranes revealed a capacity $\left(B_{\max }\right)$ ranging from $7.9 \mathrm{fmol} / \mathrm{mg}$ of membrane protein to a maximum of $102.8 \mathrm{fmol} / \mathrm{mg}$ of membrane protein, with a mean ( \pm S.E.M.) of $52.2 \pm 9.0 \mathrm{fmol} / \mathrm{mg}$ of protein $(n=10)$. This value is very much lower than that of $326.7 \pm 17.5 \mathrm{fmol} / \mathrm{mg}$ of membrane protein $(n=5)$ observed in rat liver membranes prepared by the same method.
The $\left[{ }^{3} \mathrm{H}\right] \mathrm{AVP}$-binding site in human liver was further characterized using samples which exhibited sufficient specific binding to enable competition binding experiments to be performed. A range of structural analogues with known selectivity for the neurohypophysial hormone receptors was employed (Fig. 2). $K_{d}$ values were calculated for each ligand as described in the Materials and methods section, and are presented as $\mathrm{p} K_{\mathrm{d}}$ values in Table 1 , together with the corresponding data for the rat receptor subtypes.

\section{Measurement of adenylate cyclase activity}

The ability of a saturating concentration of AVP $(1 \mu \mathrm{M})$ to stimulate adenylate cyclase was assessed in two human liver membrane preparations. The addition of forskolin $(10 \mu \mathrm{M})$ increased cyclase activity (expressed as mean \pm S.E.M.) from a basal level of $4.10 \pm 0.69 \mathrm{pmol}$ of cyclic $\mathrm{AMP} / \mathrm{min}$ per $\mathrm{mg}$ of protein to $30.97 \pm 2.00 \mathrm{pmol}$ of cyclic $\mathrm{AMP} / \mathrm{min}$ per $\mathrm{mg}$ of protein in preparation 1 and from $1.71 \pm 0.23 \mathrm{pmol} / \mathrm{min}$ per $\mathrm{mg}$ of protein to $19.46 \pm 0.21 \mathrm{pmol} / \mathrm{min}$ per $\mathrm{mg}$ of protein in preparation 2 . Incubation with AVP had no effect upon adenylate cyclase activity in either preparation. Activities after treatment with AVP were $4.16 \pm 0.28 \mathrm{pmol}$ of cyclic AMP $/ \mathrm{min}$ per $\mathrm{mg}$ of protein and $1.73 \pm 0.12 \mathrm{pmol} / \mathrm{min}$ per $\mathrm{mg}$ of protein in preparations 1 and 2 respectively.

\section{Stimulation of inositol phosphate production in human hepatocytes}

As shown in Table 2, treatment of human hepatocyte cultures with either AVP $(0.1 \mu \mathrm{M})$ or phenylephrine $(10 \mu \mathrm{M})$ stimulated an increase in the production of inositol phosphates by $37 \%$ and $35 \%$ above basal levels respectively.

\section{Stimulation of glycogen phosphorylase $a$ in hepatocytes}

Fig. 3 presents the dose-response curves of AVP-stimulated glycogen phosphorylase $a$ activity in rat and human hepatocytes. AVP increased glycogen phosphorylase $a$ activity in rat hepatocytes in a dose-dependent manner from a basal level of $0.19 \pm 0.07 \mu \mathrm{mol} / \mathrm{min}$ per $10^{6}$ cells (mean \pm S.E.M., $n=5$ ). Maximal stimulation was produced by $1 \mathrm{nM}-\mathrm{AVP}$, which increased phosphorylase $a$ activity by $680 \pm 101 \%(n=5)$ over basal, with an $\mathrm{EC}_{50}$ (concn. producing $50 \%$ activation) of 54 pM (Fig. 3). A concentration of AVP (562 pM) which ordinarily stimulated a near-maximal phosphorylase $a$ activity was without effect when

Table 1. Pharmacological characterization of the human hepatic vasopressin receptor: comparison with rat neurohypophysial hormone receptor subtypes

Data for the human hepatic vasopressin receptor are expressed as a $\mathrm{p} K_{\mathrm{d}}$ values (arithmetic means) calculated from three determinations of the $K_{\mathrm{d}}$ in separate membrane preparations. Data for the rat liver $\mathrm{V}_{1 \mathrm{a}}$ subtype are from this laboratory. Corresponding data for rat $\mathrm{V}_{1 \mathrm{~b}}$ and $\mathrm{OT}$ receptor subtypes are taken from Jard et al. $(1986,1988)$, except where indicated: *data from this laboratory. Ligand abbreviations: $\left[\mathrm{d}\left(\mathrm{CH}_{2}\right)_{5}\right.$ $\left.\operatorname{Tyr}(\mathrm{Me})^{2}\right] \mathrm{AVP}, \quad\left[1-\beta\right.$-mercapto- $\beta \beta$-cyclopentamethylenepropionic acid, $O$-methyl-Tyr $\left.{ }^{2}, \mathrm{Arg}^{8}\right]$ vasopressin; $\operatorname{des}-\mathrm{Gly}{ }^{9}-\left[\mathrm{d}\left(\mathrm{CH}_{2}\right)_{5}-\mathrm{D}-\mathrm{Tyr}(\mathrm{Et})^{2}\right] \mathrm{VAVP}$, des-Gly ${ }^{9}-\left[1-\beta\right.$-mercapto- $\beta \beta$-cyclopentamethylenepropionic acid, $O$-ethyl-D-Tyr $\left.{ }^{2}, \mathrm{Val}^{4}{ }^{4} \mathrm{Arg}^{8}\right]$ vasopressin; $\left[\mathrm{d}\left(\mathrm{CH}_{2}\right)_{5}\right.$-D-Ile $\left.^{2}, \mathrm{Ile}^{4}\right] \mathrm{AVP},[1-\beta$-mercapto$\beta \beta$-cyclopentamethylenepropionic acid,D-Ile $\left.{ }^{2}, \mathrm{Ile}^{4}, \mathrm{Arg}^{8}\right]$ vasopressin.

\begin{tabular}{|c|c|c|c|c|c|c|}
\hline \multirow[b]{3}{*}{ Ligand } & \multirow[b]{3}{*}{ Receptor... } & \multicolumn{5}{|c|}{$\mathrm{p} K_{\mathrm{d}}$ value } \\
\hline & & \multicolumn{4}{|c|}{ Rat } & \multirow{2}{*}{$\begin{array}{c}\text { Human } \\
\text { liver }\end{array}$} \\
\hline & & $\mathrm{V}_{1 \mathrm{a}}$ & $\mathrm{V}_{1 \mathrm{~b}}$ & $\mathbf{V}_{2}$ & OT & \\
\hline $\begin{array}{l}\text { AVP } \\
{\left[\mathrm{d}\left(\mathrm{CH}_{2}\right)_{5}-\mathrm{Tyr}(\mathrm{Me})^{2}\right] \mathrm{AVP}} \\
\text { des-Gly }-\left[\mathrm{d}\left(\mathrm{CH}_{2}\right)_{5}-\mathrm{D}-\mathrm{Tyr}(\mathrm{Et})^{2}\right] \text { VAVP } \\
{\left[\mathrm{d}\left(\mathrm{CH}_{2}\right)_{5}-\mathrm{D}-\mathrm{Ile}^{2}, \mathrm{Ile}^{4}\right] \mathrm{AVP}} \\
\text { OT } \\
{\left[\mathrm{Thr}^{4}, \mathrm{Gly}^{7}\right] \mathrm{OT}}\end{array}$ & & $\begin{array}{r}9.2 \\
9.6 \\
8.7 \\
5.7 \\
6.6 \\
<5.0\end{array}$ & $\begin{array}{l}8.5-9.0 \\
5.6 \\
5.7 \\
- \\
6.6 \\
-\end{array}$ & $\begin{aligned} & 9.4 \\
& 6.4 \\
& 9.4 \\
& 7.8^{*} \\
& 6.4 \\
< & 5.0\end{aligned}$ & $\begin{array}{l}8.8 \\
- \\
- \\
- \\
8.6-9.0 \\
9\end{array}$ & $\begin{array}{l}9.2 \\
8.6 \\
9.3 \\
7.5 \\
7.8 \\
6.2\end{array}$ \\
\hline
\end{tabular}


Table 2. Inositol phosphate production in human hepatocytes

Hepatocytes were prepared from the liver of a 47 -year-old male donor with a $\left[{ }^{3} \mathrm{H}\right] A V P$-binding capacity of $47.2 \mathrm{fmol} / \mathrm{mg}$ of membrane protein. Cells were cultured, labelled with myo- $\left[2-{ }^{3} \mathrm{H}\right]$ inositol, stimulated with either AVP or phenylephrine, and an Ins $P_{1}-\operatorname{Ins} P_{4}$ fraction was separated as described in the Materials and methods section. Results shown are mean values \pm S.E.M. of triplicate determinations.

\begin{tabular}{lc}
\hline Treatment & $\begin{array}{c}\text { Ins } P_{1}-\text { Ins } P_{4} \\
\left.\text { (d.p.m. } / 10^{3} \text { cells }\right)\end{array}$ \\
\hline Control & $246 \pm 23$ \\
AVP $(0.1 \mu \mathrm{M})$ & $337 \pm 12$ \\
Phenylephrine $(10 \mu \mathrm{M})$ & $331 \pm 12$
\end{tabular}

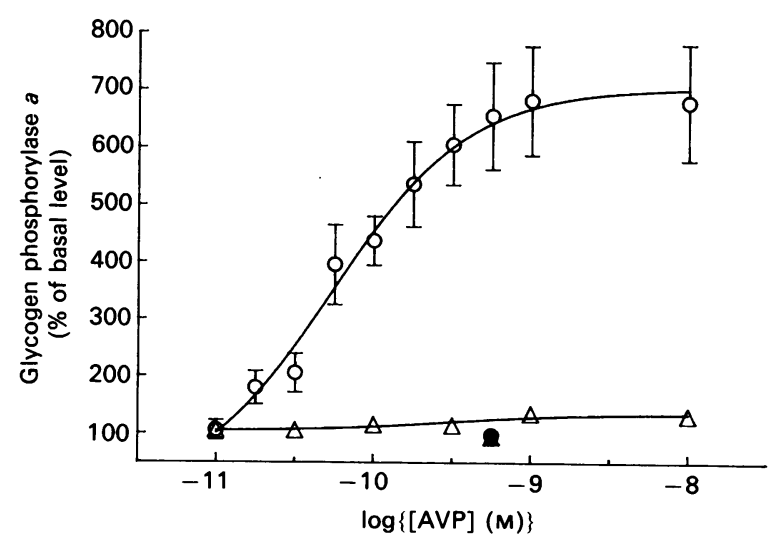

Fig. 3. Stimulation by AVP of glycogen phosphorylase $a$ activity in rat and human hepatocytes

Rat $(O)$ and human $(\triangle)$ hepatocytes were stimulated by the indicated concentrations of AVP for 2 min, then the glycogen phosphorylase $a$ activity was assayed as described in the text. The values shown are the means \pm S.E.M. of three to five separate experiments performed in duplicate, and are expressed as percentages of the basal level. Error bars for the human data are contained within the symbols. Basal levels were $0.19 \pm 0.07 \mu \mathrm{mol} / \mathrm{min}$ per $10^{6}$ cells and $0.18 \pm 0.05 \mu \mathrm{mol} / \mathrm{min}$ per $10^{6}$ cells for rat and human hepatocytes respectively. Phosphorylase $a$ activity after treatment with $10 \mathrm{nM}$-AVP was significantly higher than controls (paired Student's $t$ test, $P<0.05$ ). Closed symbols indicate the activity after incubation with AVP in the presence of $5 \mu \mathrm{M}-\left[\mathrm{d}\left(\mathrm{CH}_{2}\right)_{5}\right.$ Tyr(Me) $\left.{ }^{2}\right]$ AVP.

incubated with rat hepatocytes in the presence of an excess of the $\mathrm{V}_{1 \mathrm{a}}$-selective antagonist $\left[\mathrm{d}\left(\mathrm{CH}_{2}\right)_{5}-\mathrm{Ty}:(\mathrm{Me})^{2}\right] \mathrm{AVP}$ (Fig. 3). Rat hepatocytes also responded to glucagon, such that exposure to a maximally effective concentration of glucagon (10 nM) stimulated glycogen phosphorylase $a$ by $697 \pm 111 \%(n=4)$ over basal activity.

In contrast with rat hepatocytes, phosphorylase $a$ activity in human hepatocytes was not very responsive to AVP and increased by a maximum of only $33 \pm 10 \%(n=5)$ over the basal value of $0.18 \pm 0.05 \mu \mathrm{mol} / \mathrm{min}$ per $10^{6}$ cells $(n=6)$. This small response in human cells was nevertheless concentration-dependent, with an $\mathrm{EC}_{50}$ of approx. $280 \mathrm{pM}$ and maximal phosphorylase $a$ activity apparent with 1 nM-AVP. Furthermore, as was observed with rat hepatocytes, $\left[\mathrm{d}\left(\mathrm{CH}_{2}\right)_{5}-\mathrm{Tyr}(\mathrm{Me})^{2}\right] \mathrm{AVP}$ completely antagonized this AVP-stimulated rise in phosphorylase $a$ activity, thereby demonstrating that the stimulation was receptor-mediated. In common with rat cells, human hepatocytes were responsive to
Table 3. Comparison of $\left[{ }^{3} \mathbf{H}\right]$ thymidine incorporation in rat and human hepatocytes

All results are expressed as means \pm S.E.M. of three separate experiments performed in triplicate. The maximal response to AVP in rat hepatocytes was observed at $[\mathrm{AVP}] \leqslant 100 \mathrm{nM}$. N.D., not determined.

\begin{tabular}{|c|c|c|}
\hline \multirow[b]{2}{*}{ Treatment } & \multicolumn{2}{|c|}{$\begin{array}{c}10^{-3} \times\left[{ }^{3} \mathrm{H}\right] \mathrm{Thymidine} \\
\text { incorporation } \\
\text { (d.p.m./ } \mu \mathrm{g} \text { of DNA) }\end{array}$} \\
\hline & Rat & Human \\
\hline $\begin{array}{l}\text { Basal (no addition) } \\
\text { AVP (100 nM) } \\
\text { AVP }(5 \mathrm{nM}) \\
{\left[\mathrm{d}(\mathrm{CH})_{2}-\mathrm{Tyr}(\mathrm{Me})^{2}\right] \mathrm{AVP}(5 \mu \mathrm{M})} \\
\text { AVP }+\left[\mathrm{d}\left(\mathrm{CH}_{2}\right)_{5}-\mathrm{Tyr}(\mathrm{Me})^{2}\right] \mathrm{AVP} \\
\text { EGF }(0.85 \mathrm{nM})\end{array}$ & $\begin{array}{l}15.1 \pm 3.6 \\
27.0 \pm 3.4 \\
24.1 \pm 5.7 \\
16.1 \pm 4.1 \\
16.3 \pm 3.4 \\
92.0 \pm 34.4\end{array}$ & $\begin{array}{l}2.4 \pm 0.9 \\
2.1 \pm 0.8 \\
\text { N.D. } \\
\text { N.D. } \\
\text { N.D. } \\
14.1 \pm 6.4\end{array}$ \\
\hline
\end{tabular}

glucagon. Glycogen phosphorylase $a$ activity was increased by $298 \pm 38 \%(n=3)$ over basal after stimulation by $10 \mathrm{~nm}-$ glucagon. In control experiments, rat hepatocytes were prepared using the method employed for the production of human hepatocytes (see the Materials and methods section). A membrane preparation from these cells exhibited the same ligandbinding characteristics as membranes prepared from rat hepatocytes generated by the routine protocol. Furthermore, these hepatocytes displayed the same dose-response curve as the routinely produced rat hepatocytes with respect to AVPstimulated glycogen phosphorylase $a$ activity (results not shown).

Effect of AVP on DNA synthesis in primary hepatocyte cultures

Comparison of control rat and human hepatocyte cultures showed that mean basal levels of $\left[{ }^{3} \mathrm{H}\right]$ thymidine incorporation into DNA in rat hepatocytes was 6.3-fold higher than in human hepatocytes (Table 3). AVP treatment of rat hepatocyte cultures increased DNA synthesis in a dose-dependent manner, with a saturating concentration of AVP (100 nM) increasing $\left[{ }^{3} \mathrm{H}\right]$ thymidine incorporation into DNA by 1.8 -fold. Furthermore, the $\mathrm{V}_{1 \mathrm{a}}$-selective antagonist $\left[\mathrm{d}\left(\mathrm{CH}_{2}\right)_{5}-\mathrm{Tyr}(\mathrm{Me})^{2}\right] \mathrm{AVP}$ completely inhibited the AVP-induced increase in DNA synthesis in rat hepatocyte cultures, showing that this response to AVP was mediated by agonist occupancy of the hepatic $V_{1 a}$ receptor. In contrast, even a saturating concentration of AVP had no effect upon DNA synthesis in human hepatocyte cultures. EGF was a potent stimulant of DNA synthesis in both rat and human hepatocyte cultures. Incubation with EGF (0.85 nM) increased the incorporation of $\left[{ }^{3} \mathrm{H}\right]$ thymidine into DNA by 6.1 -fold and 5.9-fold in rat and human hepatocyte cultures respectively (Table 3).

\section{DISCUSSION}

We have studied the hitherto poorly characterized vasopressin receptor expressed by human liver and compared its characteristics to those of the well-defined $V_{1 \mathrm{a}}$ vasopressin receptor subtype expressed by rat liver. The receptors were investigated at three different levels of receptor function: (1) the interaction of ligands with the receptor and its coupled second messenger system, (2) the short-term (minutes) AVP-induced stimulation of glycogen phosphorylase $a$ activity, and (3) the long-term (days) AVP-induced increase in DNA synthesis.

$\left[{ }^{3} \mathrm{H}\right] A$ VP-binding sites were detected on human liver membranes (Fig. 1). Binding to these sites was specific, saturable 
and displayed an affinity for AVP typical of that exhibited by vasopressin receptors in the rat (Table 1). However, the receptor capacity was very much lower for human tissue than it was for the rat, with the mean $B_{\max }$ value for human liver only $16 \%$ of that observed with rat liver. Furthermore, unlike rat liver, the vasopressin receptor capacity of human liver varied considerably between donors. The physiological implications of this are not clear; however, there was no apparent relationship between the observed $B_{\max }$ and the sex or age of the donor. Pharmacological characterization of the human $\left[{ }^{3} \mathrm{H}\right] A$ VP-binding sites with selective ligands revealed that they were vasopressin receptors. In addition, the high $\mathrm{p} K_{\mathrm{d}}$ for des-Gly ${ }^{9}-\left[\mathrm{d}\left(\mathrm{CH}_{2}\right)_{5}-\mathrm{D}-\mathrm{Tyr}(\mathrm{Et})^{2} \mathrm{VAVP}\right.$ indicated that the $\mathrm{V}_{1 \mathrm{~b}}$ subtype was not expressed. Although the affinity of the $\mathrm{V}_{2}$-selective ligand $\left[\mathrm{d}\left(\mathrm{CH}_{2}\right)_{5}-\mathrm{D}-\mathrm{Ile}^{2}, \mathrm{Ile}^{4}\right] \mathrm{AVP}$ for the human hepatic vasopressin receptor was more akin to the affinity exhibited by the rat $\mathrm{V}_{2}$ rather than the rat $\mathrm{V}_{1 \mathrm{a}}$ subtype, we believe that the receptor expressed is actually the $V_{1 \mathrm{a}}$ subtype. The reason for this is threefold. First, the receptor has a high affinity for the $\mathrm{V}_{1 \mathrm{a}}$-selective ligand $\left[\mathrm{d}\left(\mathrm{CH}_{2}\right)_{5}-\mathrm{Tyr}(\mathrm{Me})^{2}\right] A V P$. Second, no stimulation by AVP of adenylate cyclase could be detected. $V_{2}$ receptors are defined as coupling to adenylate cyclase (Michell et al., 1979), hence the lack of adenylate cyclase responsiveness to AVP would preclude classifying the human liver receptor as $\mathbf{V}_{2}$. Third, activation of the receptors stimulated inositol phosphate production. Consequently, both rat and human hepato express the $V_{1 a}$ receptor. The differences in the affinity 1 of [d $\left(\mathrm{CH}_{2}\right)_{5}-\mathrm{D}-\mathrm{Ile}^{2}$,Ile $\left.\mathrm{I}^{4}\right] \mathrm{AVP}$ for the $\mathrm{V}_{1 \mathrm{a}}$ receptors of rat and human liver probably reflect a genuine species difference. Such species differences have been noticed by others when studying vasopressin antagonists in the rat and dog (Liard et al., 1982; Stassen et al., 1983). The 10-fold lower affinity of $\left[\mathrm{d}\left(\mathrm{CH}_{2}\right)_{5}-\mathrm{Tyr}(\mathrm{Me})^{2}\right] \mathrm{AVP}$ for the human $\mathrm{V}_{1 \mathrm{a}}$ receptor compared with the rat receptor would explain why $\left[{ }^{3} \mathrm{H}\right] \mathrm{AVP}$ proved to be a better tracer ligand than $\left[{ }^{3} \mathrm{H}\right]\left[\mathrm{d}\left(\mathrm{CH}_{2}\right)_{5}-\mathrm{Tyr}(\mathrm{Me})^{2}\right] A$ VP for human tissue.

Assay of glycogen phosphorylase $a$ activity was chosen as a monitor of short-term activation of hepatic vasopressin receptors, as it has been very well-characterized in the rat by many groups. The dose-response curve for AVP-stimulated phosphorylase activity in the rat (Fig. 3) was typical, as previously reported by others (e.g. Hems et al., 1976). The curve obtained using human hepatocytes was similar to this with respect to the $\mathrm{EC}_{50}$, and in that 1 nM-AVP caused maximum phosphorylase activation. However, the degree to which AVP modulated phosphorylase $a$ activity differed markedly between rat and human hepatocytes, with the mean maximum activation in the human only approx. $5 \%$ of that in the rat (Fig. 3). This small response in human hepatocytes was not due to an impaired metabolic state, as assessed by the ATP content. Furthermore, glucagon stimulated an increase in phosphorylase $a$ activity similar to that reported by others (Pieniazek et al., 1986). In addition, the reduced stimulation of glycogen phosphorylase by AVP in human cells was not due to a lack of the intracellular signalling mechanism, as both AVP and phenylephrine stimulated inositol phosphate production (Table 2). Although the extent of inositol phosphate accumulation in human cells was less than that reported for the rat (Palmer et al., 1986), it was very similar to that reported by Thakker et al. (1989) for AVP-stimulation of human hepatocytes. Thakker et al. (1989) also found that $\operatorname{PtdIns} P_{2}$ hydrolysis in human hepatocytes was similar in magnitude when mediated by either AVP receptors or $\alpha_{1}$-adrenergic receptors; this too is in agreement with our observations. The AVP-stimulated glycogen phosphorylase activation in the rat exhibits a receptor reserve, with the apparent $\mathrm{EC}_{50}$ for the response being 12-fold lower than the binding constant $\left(K_{d}\right)$ of the agonist. This is still apparent in the human, but only a 2.5 -fold difference was observed, probably reflecting the reduced number of receptors expressed by human hepatocytes. These data would imply that the role of AVP in the regulation of liver glycogen metabolism in humans is minor compared with the situation in the rat. Although the reason for this difference and its physiological ramifications are not clear, it is not a unique circumstance. Vandekerckhove et al. (1989) recently reported that the glycogen phosphorylase $a$ of rabbit hepatocytes was not modulated by AVP. In addition, the $o b / o b$ mouse hepatocyte does not express vasopressin receptors, unlike the corresponding lean controls (Assimacopoulos-Jeannet et al., 1983).

The suggestion that AVP has only a minor role in regulating human hepatic function is supported by the data on DNA synthesis. AVP has been reported to promote growth of several cell types in culture, including hepatocytes (Russell \& Bucher, 1983a,b; Hunt et al., 1977; Miller et al., 1977), and this was confirmed for rat hepatocytes (Table 3). However, although exposure of human hepatocyte cultures to EGF resulted in a pronounced stimulation of DNA synthesis, AVP was without effect.

The data presented in this paper characterize the human liver vasopressin receptor and demonstrate that marked differences exist between the rat and the human with respect to regulation of liver function by AVP. Consequently, conclusions drawn from data obtained using AVP and its analogues in rat liver cannot merely be extrapolated to the human liver.

We are grateful to Dr. M. Keen for assaying adenylate cyclase activity. This work was supported by the Medical Research Council, the Nuffield Foundation and the Royal Society.

\section{REFERENCES}

Antoni, F. A. (1984) Neuroendocrinology 39, 186-188

Assimacopoulos-Jeanet, F., Cantau, B., van de Werve, G., Jard, S. \& Jeanrenaud, B. (1983) Biochem. J. 216, 475-480

Baertschi, A. J. \& Friedli, M. (1985) Endocrinology (Baltimore) 116, 499-502

Baur, H., Kasperek, S. \& Pfaff, E. (1975) Hoppe-Seylers Z. Physiol. Chem. 356, 827-838

Belzer, F. O. \& Southard, J. H. (1988) Transplantation 45, 673-676

Berridge, M. J. \& Irvine, R. F. (1984) Nature (London) 312, 315-321

Cantau, B., Keppens, S., DeWulf, H. \& Jard, S. (1980) J. Receptor Res. 1, 137-168

Cheng, Y. \& Prusoff, W. H. (1973) Biochem. Pharmacol. 22, 3099-3108

Dickey, B. F., Fishman, J. B., Fine, R. F. \& Navarro, J. (1987) J. Biol. Chem. 262, 8738-8742

Hems, D. A. \& Whitton, P. D. (1973) Biochem. J. 136, 705-709

Hems, D. A. \& Whitton, P. D. (1980) Physiol. Rev. 60, 1-50

Hems, D. A., Whitton, P. D. \& Ma, G. Y. (1975) Biochim. Biophys. Acta 411, 155-164

Hems, D. A., Rodrigues, L. M. \& Whitton, P. D. (1976) Biochem. J. 160, 367-374

Hems, R., Ross, B. D., Berry, M. N. \& Krebs, H. A. (1966) Biochem. J. 101, 284-292

Hunt, N. H., Perris, A. D. \& Sandford, P. A. (1977) J. Endocrinol. 72, 5-16

Jard, S. (1983) Curr. Top. Membr. Transp. 18, 255-285

Jard, S., Gaillard, R. C., Guillon, G., Marie, J., Schoenenberg, P., Muller, A. F., Manning, M. \& Sawyer, W. H. (1986) Mol. Pharmacol. 30, 171-177

Jard, S., Elands, J., Schmidt, A., Tribollet, E., Manning, M. \& Sawyer, W. H. (1988) in Recent Progress in Posterior Pituitary Hormones (Yoshida, S. \& Share, L., eds.), pp. 313-320, Elsevier, Amsterdam

Keen, M., Kelly, E., Nobbs, P. \& MacDermot, J. (1989) Biochem. Pharmacol. 38, 3827-3833

Keppens, S. \& DeWulf, H. (1975) FEBS Lett. 51, 29-32

Keppens, S. \& DeWulf, H. (1979) Biochim. Biophys. Acta 588, 63-69

Keppens, S., Vandenheede, J. R. \& DeWulf, H. (1977) Biochim. Biophys. Acta 496, 448-457

Kirk, C. J. \& Hems, D. A. (1974) FEBS Lett. 47, 128-131 
Kirk, C. J., Rodrigues, L. M. \& Hems, D. A. (1979) Biochem. J. 178, 493-496

Kirk, C. J., Michell, R. H. \& Hems, D. A. (1981) Biochem. J. 194, 155-165

Kirk, C. J., Guillon, G., Balestre, M.-N. \& Jard, S. (1986) Biochem. J. 240, 197-204

Knepel, W., Homolka, L. \& Vlaskovska, M. (1983) Eur. J. Pharmacol. 91, 115-118

Kruszynski, M., Lammek, B., Manning, M., Seto, J., Haldar, J. \& Sawyer, W. H. (1980) J. Med. Chem. 23, 364-368

Liard, J. F., Deriaz, O., Schelling, P. \& Thibonner, M. (1982) Am. J. Physiol. 243, H663-H669

Lowbridge, J., Manning, M., Haldar, J. \& Sawyer, W. H. (1977) J. Med. Chem. 20, 120-123

Manning, M., Nawrocka, E., Misicka, A., Olma, A., Klis, W. A., Seto, J. \& Sawyer, W. H. (1984) J. Med. Chem. 27, 423-429

McGowan, J. A., Strain, A. J. \& Bucher, N. L. R. (1981) J. Cell. Physiol. 108, 353-363

Michell, R. H., Kirk, C. J. \& Billah, M. M. (1979) Biochem. Soc. Trans. 7, 861-865

Miller, R. P., Husain, F., Svensson, M. \& Lohin, S. (1977) Endocrinology (Baltimore) 100, 1365-1375

Palmer, S., Hawkins, P. T., Michell, R. H. \& Kirk, C. J. (1986) Biochem. J. 238, 491-499

Pieniazek, D., Pronicka, E. \& Pawtowska, J. (1986) Horm. Metab. Res. 18, 546-550
Raymond, V., Leung, P. C. K., Veilleux, R. \& Labrie, F. (1985) FEBS Lett. 182, 196-200

Ross, H., Marshall, V. C. \& Escott, M. O. (1976) Transplantation 21, 498-501

Russell, W. E. \& Bucher, N. L. R. (1983a) Am. J. Physiol. 245, G321-G324

Russell, W. E. \& Bucher, N. L. R. (1983b) in Isolation, Characterization and Use of Hepatocytes (Harris, R. A. \& Cornell, N. N., eds.), pp. 145-154, Elsevier, New York

Salomon, Y., London, D. \& Rodbell, M. (1974) Anal. Biochem. 58, 541-548

Sharma, S. K., Nirenberg, M. \& Klee, W. A. (1975) Proc. Natl. Acad. Sci. U.S.A. 72, 590-594

Stassen, F. L., Bryan, W., Gross, M., Kavanagh, B., Shue, L., Sulat, V. D., Wiebelhaus, N., Yim, N. \& Kinter, L. B. (1983) Prog. Brain Res. 60, 395-403

Strain, A. J., McGowan, J. A. \& Bucher, N. L. R. (1982) In Vitro 18, 108-116

Strain, A. J., Ismail, T., Tsubouchi, H., Arakaki, N., Hishida, T., Kitamura, N., Daikuhara, Y. \& McMaster, P. (1991) J. Clin. Invest., in the press

Thakker, J. K., DiMarchi, R., MacDonald, K. \& Caro, J. F. (1989) J. Biol. Chem. 264, 7169-7175

Vandekerckhove, A., Miot, F., Keppens, S. \& DeWulf, H. (1989) Biochem. J. 259, 609-611

Received 14 August 1990/30 January 1991; accepted 4 February 1991 